\title{
THE RELATIONSHIP BETWEEN TURKISH EFL STATE SCHOOL TEACHERS' CULTURAL INTELLIGENCE AND THEIR PROFESSIONAL WELL-BEING
}

\author{
İ. EFE EFEOĞLU \\ School of Foreign Languages, \\ Adana Science and Technology University, Adana, Turkey \\ E-mail address: efeoglu@adanabtu.edu.tr \\ ÖMER GÖKHAN ULUM \\ School of Foreign Languages, \\ Adana Science and Technology University, Adana, Turkey \\ E-mail address: gokhanulum@adanabtu.edu.tr
}

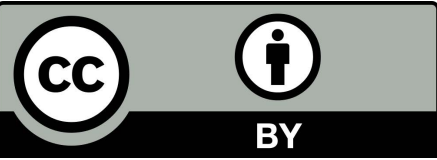

\begin{abstract}
Cultural intelligence can be described as the ability of a person to behave adequately in culturally diverse environments. It involves comprehending the effects of cultural background on the attitudes of people for auspicious participation in any social setting. Cultural intelligence may be positively and significantly correlated with professional wellbeing among English as foreign language (EFL) teachers. So, the present study sought to investigate the correlation between Turkish EFL state school teachers' cultural intelligence and their professional well-being. A sample including $120 \mathrm{EFL}$ state school teachers completed two questionnaires: (1) Cultural Intelligence Scale developed by Cultural Intelligence Center (2005); and (2) the Scale of Teacher Perception of Professional Well-Being developed by Yildirim, Arastaman and Dasci (2016). The results of the study indicated significant correlations between Turkish EFL state school teachers' cultural intelligence and their professional well-being. This study may help English Language Teaching (ELT) departments to implement materials within their curriculum for aiding EFL teachers in terms of developing cultural intelligence. Furthermore, this paper makes a unique contribution to the area of cultural intelligence by identifying whether there is a relationship between cultural intelligence and professional well-being.

Key words: EFL Teachers, Cultural Intelligence, Professional Well-being, ELT Departments
\end{abstract}

\section{INTRODUCTION}

Being the collective programming of the brain which sorts out the individuals of one community from another (Hofstede, 1980), culture is transmitted 
from one generation to another and usually evolves since every generation supplements its peculiar characteristics just before passing them on (Matsumoto, 1996; Belshek, 2006). Besides referring to a set of approaches, beliefs, and values owned by a society, but diverse for each member of a group of people, culture is a fuzzy collection of fundamental inferences, adaptations to life, and social practices belonging to a group of individuals, which affects but does not rule individuals' attitudes, (Spencer-Oatey, 2008).

Furthermore, culture is pinned on intelligence and that cultural intelligence is an issue recently studied by researchers in various fields. The rising curiosity in intelligence has given way to new kinds of intelligences based on particular areas such as social intelligence (Thorndike, \& Stein, 1937) and emotional intelligence (Mayer, \& Salovey, 1993). However, in terms of cross-cultural dimensions, both emotional and social intelligence domains are short of cultural background as they only try to describe how and why individuals respond (Sternberg, 1997). Cultural intelligence is explained as an entity of cooperating knowledge and skills, tied with cultural metacognition, which lets individuals frame and adapt to the cultural dimensions of their surroundings. There being varied notions of intelligence, cultural intelligence not only contains diversified sorts of data and skills, but also covers cognitive and metacognitive facets (Thomas et al., 2008). Metacognitive cultural intelligence concentrates on higher-order cognitive practices, while cognitive cultural intelligence mirrors knowledge of the norms, customs, and traditions in diverse cultures gained by training and individual experiences. This covers the knowledge of the financial, formal and social programming of distinguished cultures (Triandis, 1994), as well as the knowledge of primary cores of cultural values (Hofstede, 2001). People having enhanced cognitive cultural intelligence comprehend multicultural similarities and differences (Brislin, Worthley, \& MacNab, 2006).

One may ask whether there is a relationship between cultural intelligence and professional well-being, or how particular reasons influence professional well-being. Predictor variables of professional well-being are personal characteristics, workload, role stress, and social support. In most studies of professional well-being, there exist background features that may protect a person from threats to professional well-being and among the features frequently stated in the related literature are the age, educational level, and work experience of the individual. Besides the individual features, scholars have suggested that facets of the work setting also play a fundamental role in touching professional well-being. Workload and role stress refer to the outstanding work environment features, and role ambiguity as a scope of role stress in the workplace means a shortage of precision regarding the missions and responsibilities linked to a peculiar work role. It is crystal clear that those with low levels of social support bear the potential of encountering job burnout (Munn, Berber, \& Fritz, 1996). Job satisfaction, commitment and depression are just some of the main variables of occupational psychology, while motivation, competence and efficacy are broader terms of professional well-being. Multifaceted ways of measuring well-being may lead to more accurate evaluations of the relation- 
ships between professional well-being and other terms, therefore supporting our comprehension of reasons and results of occupational well-being (Horn, Taris, Schaufeli, \& Schreurs, 2004). Several researches have inquired about the effect of work and careers on job related and non-job related intellectual wellness. Yet, there is still a lack of tools whose psychometric features have been concluded by the data from large samples of staff and various occupational levels. Notably, there is a requirement for measures which can supply data about affective well-being (Warr, 1990). Bearing all these in mind, the present study examined the correlation between Turkish EFL state school teachers' cultural intelligence and their professional well-being.

\section{RESEARCH QUESTIONS}

This study focuses on the correlation between Turkish EFL state school teachers' cultural intelligence and their professional well-being and aims to seek answers to the following research questions:

1. How do Turkish EFL state school teachers perceive their cultural intelligence?

2. How do Turkish EFL state school teachers perceive their professional well-being?

3. What is the relationship between cultural intelligence and professional well-being of Turkish EFL state school teachers?

\section{METHOD}

\section{Participants}

The EFL teachers participating in this research were selected from the most convenient and accessible schools located in Adana, Turkey. The sample consisted of 120 Turkish EFL state school teachers who were volunteers to participate in the study. Great care was taken to choose urban, suburban and rural schools from diverse populations that mirror the composition of teachers. In choosing the participants, the convenience sampling method was employed as the target population was too large, and therefore, not accessible.

\section{Data Collection Tools}

In this study, perceptions towards cultural intelligence and professional well-being were measured by means of two questionnaires: (1) Cultural Intelligence Scale developed by Cultural Intelligence Center (2005); and (2) the Scale of Teacher Perception of Professional Well-Being developed by Yildirim, Arastaman and Dasci (2016). This study was conducted having resource to the descriptive research design with the aim of comprehending the perspectives of Turkish EFL state school teachers pertaining to their cultural intelligence and professional well-being, as well as the relationship between both aspects. The data was collected from a group of Turkish EFL state school teachers working 
in Adana by means of two questionnaires, which were directly administered to the target group by the researcher. Based upon a descriptive research design, this study contained the data analysis of descriptive statistics. In this sense, SPSS 20.0, a Statistical Program for Social Sciences was exploited to report participants' viewpoints in numerical data. In order to analyze the data gathered from the questionnaires, mean $(\overline{\mathrm{x}})$ was used as a statistical technique in order to find out the rate of agreement related to the items of the questionnaires. The scorings below were used in order to compare the mean values $(\bar{x})$ of the views specified.
1. far below
2. moderately below
3. slightly below
4. met expectations
$: 3.58-4.43$
5. slightly above
6. moderately above
$: 5.30-6.14$
7. far above
$: 6.15-7.00$

\section{DATA ANALYSIS AND RESULTS}

In this part, the results of the research and the findings are explained referring to the data gained from the participants by means of the instruments. The results and the findings are explained based on the related research questions. They are grouped under the titles of the categories from the questionnaires.

\section{Findings pertaining to the Cultural Intelligence and Professional}

Well-being

In this section, results and discussion related to the perspectives of Turkish EFL teachers on cultural intelligence and professional well-being are included. The following tables represent the results pertaining to the dimensions mentioned.

\section{Results Pertaining to Cultural Intelligence}

There are 4 categories related to the perceptions of Turkish EFL teachers on cultural intelligence in the questionnaire. Table 1 clarifies the results pertaining to the perspectives of the participants on metacognitive factors of cultural intelligence, while Table 2 represents the cognitive factors related to cultural intelligence. Table 3 displays motivational factors of cultural intelligence, while Table 4 presents behavioral factors of cultural intelligence. 
Table 1

Metacognitive Factors

\begin{tabular}{lccc}
\hline \multicolumn{1}{c}{ Items } & $\mathbf{N}$ & Ss & $(\overline{\mathrm{x}})$ \\
\hline $\begin{array}{l}\text { 1. I check the accuracy of my cultural knowledge } \\
\text { as I interact with people from different cultures. }\end{array}$ & 120 & 1.060 & 5.96 \\
\hline $\begin{array}{l}\text { 2. I am conscious of the cultural knowledge I use } \\
\text { when interacting with people with different cultural } \\
\text { backgrounds. }\end{array}$ & 120 & 1.104 & 5.91 \\
\hline $\begin{array}{l}\text { 3. I am conscious of the cultural knowledge I apply } \\
\text { to cross-cultural interactions. }\end{array}$ & 120 & .948 & 5.91 \\
\hline $\begin{array}{l}\text { 4. I adjust my cultural knowledge as I interact with } \\
\text { people from a culture that is unfamiliar to me. }\end{array}$ & 120 & 1.032 & 5.90 \\
\hline Valid N (listwise) 120 & & & \\
\hline
\end{tabular}

First of all, for the $1^{\text {st }}$ item, regarding I check the accuracy of my cultural knowledge as I interact with people from different cultures, it is clearly understood from the table that the mean $(\bar{x})$ score for this part is 5.96. This score indicates that Item 1 is mostly agreed by the participants. When it comes to the $2^{\text {nd }}$ item, regarding I am conscious of the cultural knowledge I use when interacting with people with different cultural backgrounds one can easily understand from the table that the mean $(\bar{x})$ score for this item is 5.91, while it is 5.91 for the $3^{\text {rd }}$ item I am conscious of the cultural knowledge I apply to cross-cultural interactions as well, which clearly indicate that Item 2 and 3 are also mostly agreed by the participants following the $1^{\text {st }}$ item. Furthermore, the $4^{\text {th }}$ item I adjust my cultural knowledge as I interact with people from a culture that is unfamiliar to me is also mostly agreed by the participants, with a mean $(\bar{x})$ score of 5.90 .

Table 2

Cognitive Factors

\begin{tabular}{cccc}
\hline Items & $\mathbf{N}$ & Ss & $(\mathbf{x} \square)$ \\
\hline 5. I know the cultural values and religious beliefs & 120 & 1.366 & 5.32
\end{tabular}
of other cultures.

\begin{tabular}{lllll}
\hline 6. I know the legal and economic systems of & 120 & 1.157 & 5.06
\end{tabular}
other cultures.

\begin{tabular}{lllll}
\hline 7. I know the rules (e.g., vocabulary, grammar) of & 120 & 1.469 & 5.02
\end{tabular} other languages.

\begin{tabular}{llll}
\hline 8. I know the arts and crafts of other cultures. & 120 & 1.353 & 4.75 \\
\hline 9. I know the marriage systems of other cultures. & 120 & 1.511 & 4.68 \\
\hline $\begin{array}{l}\text { 10. I know the rules for expressing non-verbal } \\
\text { behaviour in other cultures. }\end{array}$ & 120 & 1.504 & 4.57 \\
\hline Valid N (listwise) 120 & & & \\
\hline
\end{tabular}


In terms of the $5^{\text {th }}$ item, regarding I know the cultural values and religious beliefs of other cultures, the mean $(\bar{x})$ score for this part is 5.32, which mean that Item 5 is mostly agreed by the participants. On the other hand, as it is clear from the table, the participants slightly agree about the $6^{\text {th }}$ item I know the legal and economic systems of other cultures with a mean $(\bar{x})$ score 5.06 , the $7^{\text {th }}$ item I know the rules (e.g., vocabulary, grammar) of other languages with a mean $(\bar{x})$ score 5.02 , the $8^{\text {th }}$ item $I$ know the arts and crafts of other cultures with a mean $(\bar{x})$ score 4.75 , the $9^{\text {th }}$ item I know the marriage systems of other cultures with a mean $(\bar{x})$ score 4.68 , and the $10^{\text {th }}$ item $I$ know the rules for expressing non-verbal behaviour in other cultures with a mean $(\bar{x})$ score 4.57 .

Table 3

Motivational Factors

\begin{tabular}{lccc}
\hline \multicolumn{1}{c}{ Items } & N & Ss & $(\overline{\mathrm{x}})$ \\
\hline $\begin{array}{l}\text { 11. I enjoy interacting with people from different } \\
\text { cultures. }\end{array}$ & 120 & 1.084 & 6.24 \\
\hline $\begin{array}{l}\text { 12. I am confident that I can socialise with locals } \\
\text { in a culture that is unfamiliar to me. }\end{array}$ & 120 & 1.124 & 6.14 \\
\hline $\begin{array}{l}\text { 13. I am sure I can deal with the stresses of } \\
\text { adjusting to a culture that is new to me. }\end{array}$ & 120 & 1.162 & 5.90 \\
\hline $\begin{array}{l}\text { 14. I am confident that I can get accustomed to } \\
\text { the shopping conditions in a different culture. }\end{array}$ & 120 & 1.166 & 5.75 \\
\hline $\begin{array}{l}\text { 15. I enjoy living in cultures that are unfamiliar } \\
\text { to me. }\end{array}$ & 120 & 1.416 & 5.70 \\
\hline Valid N (listwise) 120 & & & \\
\hline
\end{tabular}

Regarding the $11^{\text {th }}$ item I enjoy interacting with people from different cultures, the table illustrates that the mean $(\bar{x})$ score is 6.24 which means that the participants completely agree about this item. Moreover, in terms of the $12^{\text {th }}$ item $I$ am confident that I can socialise with locals in a culture that is unfamiliar to me with a mean $\left(\bar{x}\right.$ score 6.14 , the $13^{\text {th }}$ item I am sure I can deal with the stresses of adjusting to a culture that is new to me with a mean $(\bar{x})$ score 5.90 , the $14^{\text {th }}$ item I am confident that I can get accustomed to the shopping conditions in a different culture with a mean $(\bar{x})$ score 5.75 , and the $15^{\text {th }}$ item I enjoy living in cultures that are unfamiliar to me with a mean $(\bar{x})$ score 5.70 , it is easily understood that the participants mostly agree about these items. 
Table 4

Behavioral Factors

\begin{tabular}{lccc}
\hline \multicolumn{1}{c}{ Items } & N & Ss & $(\overline{\mathrm{x}})$ \\
\hline $\begin{array}{l}\text { 16. I change my non-verbal behaviour when a } \\
\text { cross-cultural situation requires it. }\end{array}$ & 120 & 1.110 & 5.40 \\
\hline $\begin{array}{l}\text { 17. I vary the rate of my speaking when a cross- } \\
\text { cultural situation requires it. }\end{array}$ & 120 & 1.223 & 5.37 \\
\hline $\begin{array}{l}\text { 18. I use pause and silence differently to suit } \\
\text { different cross-cultural situations. }\end{array}$ & 120 & 1.398 & 5.16 \\
\hline $\begin{array}{l}\text { 19. I alter my facial expressions when a cross- } \\
\text { cultural interaction requires it. }\end{array}$ & 120 & 1.493 & 5.10 \\
\hline $\begin{array}{l}\text { 20. I change my verbal behaviour (e.g., accent, tone) } \\
\text { when a cross-cultural interaction requires it. }\end{array}$ & 120 & 1.694 & 5.05 \\
\hline Valid N (listwise) 120 & & & \\
\hline
\end{tabular}

For the $16^{\text {th }}$ and $17^{\text {th }}$ items, it is clearly observed from the table that they are mostly agreed by the participants by looking at the mean $(\bar{x})$ scores: 5.40 for the first one (I change my non-verbal behaviour when a cross-cultural situation requires it), and 5.37 for the second one (I vary the rate of my speaking when a cross-cultural situation requires $i t)$. B and, for the $18^{\text {th }}$ item I use pause and silence differently to suit different cross-cultural situations, the mean $(\bar{x})$ score 5.16, for the $19^{\text {th }}$ item I alter my facial expressions when a cross-cultural interaction requires, the mean $(\bar{x})$ score 5.10 , and for the $20^{\text {th }}$ item I change my verbal behaviour (e.g., accent, tone) when a cross-cultural interaction requires it, the mean $(\bar{x})$ score 5.05 simply display that these items are slightly agreed by the participants.

\section{Results Pertaining to Professional Well-being}

There are 3 categories related to the perceptions of Turkish EFL teachers on professional well-being in the questionnaire. Table 5 clarifies the results pertaining to the perspectives of the participants on self-efficacy, while Table 6 represents recognition., Table 7 displays professional collaboration and sharing. 
Table 5

\section{Self-efficacy}

\begin{tabular}{|c|c|c|c|}
\hline Items & $\mathbf{N}$ & Ss & $(\bar{x})$ \\
\hline 1. I know the rules required by my profession. & 120 & 919 & 6.14 \\
\hline $\begin{array}{l}\text { 2. I have the knowledge and skills that I can } \\
\text { easily employ in my job. }\end{array}$ & 120 & 1.092 & 6.01 \\
\hline $\begin{array}{l}\text { 3. I incorporate the professional theoretical } \\
\text { knowledge into practice. }\end{array}$ & 120 & 1.068 & 5.98 \\
\hline 4. I seek new ways to do my job more effectively. & 120 & 1.048 & 5.95 \\
\hline 5. I make my own professional decisions. & 120 & 1.168 & 5.88 \\
\hline $\begin{array}{l}\text { 6. I know how to reach individuals (students, } \\
\text { parents, employees). }\end{array}$ & 120 & 1.055 & 5.83 \\
\hline 7. I follow the latest innovations in my profession. & 120 & 1.183 & 5.80 \\
\hline 8. I try new things in my job. & 120 & 1.124 & 5.71 \\
\hline $\begin{array}{l}\text { 9. I decide on the professional tools and } \\
\text { equipment used at my workplace. }\end{array}$ & 120 & 1.235 & 5.54 \\
\hline 10. I feel that I am professionally very good. & 120 & 1.091 & 5.54 \\
\hline $\begin{array}{l}\text { 11. I can fulfil what is required by my job } \\
\text { effectively even under most challenging } \\
\text { circumstances if I need to }\end{array}$ & 120 & 1.250 & 5.49 \\
\hline $\begin{array}{l}\text { 12. I can perform my profession successfully } \\
\text { anywhere. }\end{array}$ & 120 & 1.460 & 5.45 \\
\hline 13. I decide on the innovative practices at my job myself. & 120 & 1.160 & 5.38 \\
\hline Valid N (listwise) 120 & & & \\
\hline
\end{tabular}

Table 5 clearly represents that the $1^{\text {st }}$ item I know the rules required by my profession with a mean $(\bar{x})$ score 6.14 , the $2^{\text {nd }}$ item I have the knowledge and skills that I can easily employ in my job with a mean $(\bar{x})$ score 6.01 , the $3^{\text {rd }}$ item I incorporate the professional theoretical knowledge into practice with a mean $(\bar{x})$ score 5.98 , the $4^{\text {th }}$ item I seek new ways to do my job more effectively with a mean $(\bar{x})$ score 5.95 , the $5^{\text {th }}$ item I make my own professional decisions with a mean $(\bar{x})$ score 5.88 , the $6^{\text {th }}$ item I know how to reach individuals (students, parents, employees) with a mean $(\overline{\mathrm{x}})$ score 5.83 , the $7^{\text {th }}$ item I follow the latest innovations in my profession with a mean $(\bar{x})$ score 5.80 , the $8^{\text {th }}$ item I try new things at my job with a mean $(\bar{x})$ score 5.71 , the $9^{\text {th }}$ item I decide on the professional tools and equipment used at my workplace with a mean $(\overline{\mathrm{x}})$ score 5.54, the $10^{\text {th }}$ item I feel that I am professionally very good with a mean $(\bar{x})$ score 5.54 , the $11^{\text {th }}$ item I can fulfil what is required by my job effectively even under most challenging circumstances if I need to with a mean $(\bar{x})$ score 5.49 , the $12^{\text {th }}$ item I can perform my profession successfully anywhere with a mean $(\bar{x})$ score 5.45 , and the $13^{\text {th }}$ item I decide on the innovative practices at my job myself with a mean $(\bar{x})$ score 5.38 are all mostly agreed by the participants. 
Table 6

Recognition

\begin{tabular}{|c|c|c|c|}
\hline Items & $\mathbf{N}$ & Ss & $(\bar{x})$ \\
\hline $\begin{array}{l}\text { 14. I regularly read professional publications (books, } \\
\text { magazines, articles...). }\end{array}$ & 120 & 1.474 & 5.19 \\
\hline 15. I can achieve my professional goals where I work. & 120 & 1.392 & 5.19 \\
\hline $\begin{array}{l}\text { 16. I am appreciated for my professional } \\
\text { accomplishments. }\end{array}$ & 120 & 1.748 & 5.03 \\
\hline $\begin{array}{l}\text { 17. I hold useful discussions with the school } \\
\text { administration on professional matters. }\end{array}$ & 120 & 1.671 & 4.94 \\
\hline $\begin{array}{l}\text { 18. My profession is highly respected in my } \\
\text { environment. }\end{array}$ & 120 & 1.739 & 4.84 \\
\hline 19. I have exciting future plans about my profession. & 120 & 1.843 & 4.75 \\
\hline $\begin{array}{l}\text { 20. I am appreciated by the administration for my } \\
\text { professional accomplishments. }\end{array}$ & 120 & 1.810 & 4.50 \\
\hline Valid N (listwise) 120 & & & \\
\hline
\end{tabular}

It is clearly understood from Table 6 that the $14^{\text {th }}$ item I regularly read professional publications (books, magazines, articles...) with a mean $(\bar{x})$ score 5.19 , the $15^{\text {th }}$ item I can achieve my professional goals where I work with a mean $(\bar{x})$ score 5.19, the $16^{\text {th }}$ item I am appreciated for my professional accomplishments with a mean $(\bar{x})$ score 5.03 , the $17^{\text {th }}$ item I hold useful discussions with the school administration on professional matters with a mean $(\overline{\mathrm{x}})$ score 4.94 , the $18^{\text {th }}$ item My profession is highly respected in my environment with a mean $(\bar{x})$ score 4.84 , the $19^{\text {th }}$ item I have exciting future plans about my profession with a mean $(\bar{x})$ score 4.75 , and the $20^{\text {th }}$ item I am appreciated by the administration for my professional accomplishments with a mean $(\bar{x})$ score 4.50 are all slightly agreed by the participants.

Table 7

Professional Collaboration and Sharing

\begin{tabular}{lccc}
\hline \multicolumn{1}{c}{ Items } & $\mathbf{N}$ & Ss & $(\bar{x})$ \\
\hline $\begin{array}{l}\text { 21. I exchange views on professional matters with } \\
\text { concerned friends. }\end{array}$ & 120 & 1.110 & 6.10 \\
\hline
\end{tabular}

22. I share perspectives, techniques and tools which $\quad 120 \quad 1.311 \quad 5.94$ I believe to be effective with my friends.

\begin{tabular}{llll}
\hline $\begin{array}{l}\text { 23. I ask my friends for help to develop myself } \\
\text { professionally. }\end{array}$ & 120 & 1.275 & 5.43 \\
\hline $\begin{array}{l}\text { 24. I make professional decisions together with my } \\
\text { colleagues. }\end{array}$ & 120 & 1.294 & 5.42 \\
\hline Valid N (listwise) 120 & & & \\
\hline
\end{tabular}


By looking at Table 7 , one can easily understand that the $21^{\text {st }}$ item I exchange views on professional matters with concerned friends with a mean $(\bar{x})$ score 6.10, the $22^{\text {nd }}$ item I share perspectives, techniques and tools which I believe to be effective with my friends with a mean $(\bar{x})$ score 5.94 , the $23^{\text {rd }}$ item I ask my friends for help to develop myself professionally with a mean $(\bar{x})$ score 5.43 , and the $24^{\text {th }}$ item I make professional decisions together with my colleagues with a mean $(\bar{x})$ score 5.42 are all mostly agreed by the participants.

\section{DISCUSSION AND CONCLUSION}

A number of studies have been conducted to examine the relation of cultural intelligence with different factors (Ang et al., 2007; Kim, Kirkman, \& Chen, 2008; Oolders, Chernyshenko, \& Stark, 2008; Crowne, 2009; Elenkov, \& Manev, 2009; Amiri, Moghimi, \& Kazemi, 2010; Lee, \& Sukoco, 2010; Imai, \& Gelfand, 2010; Moon, 2010; Subramaniam, Ramalu, Wei, \& Rose, 2011; Khani, Etebarian, \& Abzari, 2011; Keung, 2011; Lovvorn, \& Chen, 2011; Chen, Lin, \& Sawangpattanakul, 2011; Balogh, Gaál, \& Szabó, 2011; Nafei, 2013; Anvari, Irum, Ashfaq, \& Atiyaye, 2014; Bücker, Furrer, Poutsma, \& Buyens, 2014), however it is not easy to see such studies inquiring into the relation between cultural intelligence and professional well-being. That was the reason for this study aimed at investigating the relation between cultural intelligence and professional well-being. In other words, the present study focused on examining the relation between Turkish EFL teachers' cultural intelligence and their professional well-being. It was figured out that metacognitive cultural intelligence factors were mostly adopted by all of the participants, while motivational and behavioral cultural intelligence factors were adopted by most of them. On the other hand, only cognitive cultural intelligence factors were slightly adopted by most of the participants. Furthermore, when looking at the sub-dimensions of the professional well-being, while self-efficacy, and professional collaboration and sharing were mostly affirmed by all of the respondents, recognition was slightly approved by most of them. The respondents in the study neither disagreed nor were neutral about the items. So, when looking at the overall results of the study, it can easily be understood that the findings of cultural intelligence and professional well-being were directly proportional, in that those representing culturally intelligent characteristics also reflected the features of professional well-being.

\section{REFERENCES}

1. Amiri, A. N., Moghimi, S. M., \& Kazemi, M. (2010). Studying the relationship between cultural intelligence and employees' performance. European journal of scientific Research, 42(3). 418-427.

2. Ang, S., Van Dyne, L., Koh, C., Ng, K. Y., Templer, K. J., Tay, C., \& Chandrasekar, N. A. (2007). Cultural intelligence: Its measurement and effects on cultural judgment and decision making, cultural adaptation and task performance. Management and organization review, 3(3). 335-371. 
3. Anvari, R., Irum, S., Ashfaq, M., \& Atiyaye, D. M. (2014). The impact of leader's cultural intelligence on organizational commitment. Asian Social Science, 10(17). 45.

4. Balogh, A., Gaál, Z., \& Szabó, L. (2011). Relationship between organizational culture and cultural intelligence. Management \& Marketing, 6(1). 95.

5. Belshek, J. A. (2006). The influence of culture on the negotiation styles of British students. Annual review of education, communication and language sciences. 3.

6. Brislin, R., Worthley, R., \& MacNab, B. (2006). Cultural intelligence: Understanding behaviors that serve people's goals. Group and Organization Management. 31: 40-55.

7. Bücker, J. J., Furrer, O., Poutsma, E., \& Buyens, D. (2014). The impact of cultural intelligence on communication effectiveness, job satisfaction and anxiety for Chinese host country managers working for foreign multinationals. The International Journal of Human Resource Management, 25(14). 2068-2087.

8. Chen, A. S. Y., Lin, Y. C., \& Sawangpattanakul, A. (2011). The relationship between cultural intelligence and performance with the mediating effect of culture shock: A case from Philippine laborers in Taiwan. International Journal of Intercultural Relations, 35(2). 246-258.

9. Crowne, K. A. (2009). The relationships among social intelligence, emotional intelligence and cultural intelligence. Organization Management Journal, 6(3). 148-163.

10. Cultural Intelligence Center. (2005). The Cultural Intelligence Scale (CQS). Retrieved on the $1^{\text {st }}$ of April, 2017 from www.linnvandyne.com/papers/The\%20CQS.pdf.

11. Elenkov, D. S., \& Manev, I. M. (2009). Senior expatriate leadership's effects on innovation and the role of cultural intelligence. Journal of World Business, 44(4). 357-369.

12. Hofstede, G. (1980). Culture's Consequences: International Differences in Work- related Values. London: Sage Publications.

13. Hofstede, G. (2001). Culture's consequences: Comparing values, behaviors, institutions, and organizations across nations. Thousand Oaks, Calif: Sage.

14. Horn, J. E., Taris, T. W., Schaufeli, W. B., \& Schreurs, P. J. (2004). The structure of occupational well-being: A study among Dutch teachers. Journal of occupational and Organizational Psycho$\log y, 77(3)$. 365-375.

15. Imai, L., \& Gelfand, M. J. (2010). The culturally intelligent negotiator: The impact of cultural intelligence (CQ) on negotiation sequences and outcomes. Organizational Behavior and Human Decision Processes, 112(2). 83-98.

16. Keung, E. K. (2011). What factors of cultural intelligence predict transformational leadership: A study of international school leaders (Doctoral dissertation, Liberty University).

17. Khani, A., Etebarian, A., \& Abzari, M. (2011). The relationship between cultural intelligence and group effectiveness in Mobarakeh steel company. African Journal of Business Management, 5(17). 7507.

18. Kim, K., Kirkman, B. L., \& Chen, G. (2008). Cultural intelligence and international assignment effectiveness. Handbook of cultural intelligence: Theory, measurement, and applications. 71-90.

19. Lee, L. Y., \& Sukoco, B. M. (2010). The effects of cultural intelligence on expatriate performance: The moderating effects of international experience. The International Journal of Human Resource Management, 21(7). 963-981.

20. Lovvorn, A. S., \& Chen, J. S. (2011). Developing a global mindset: The relationship between an international assignment and cultural intelligence. International Journal of Business and Social Science, 2(9).

21. Matsumoto, D. (1996). Culture and Psychology. Pacific Grove, CA: Brooks/Cole.

22. Mayer, J. D., \& Salovey, P. (1993). The intelligence of emotional intelligence. Intelligence, 17(4). 433-442.

23. Moon, T. (2010). Emotional intelligence correlates of the four-factor model of cultural intelligence. Journal of Managerial Psychology, 25(8). 876-898.

24. Munn, E. K., Munn, P. C., Berber, C. E., \& Fritz, J. J. (1996). Factors affecting the professional well-being of child life specialists. Children's Health Care, 25(2). 71-91.

25. Nafei, W. A. (2013). The impact of cultural intelligence on employee job performance: an empirical study on King Abdel-Aziz Hospital in Al-Taif Governorate, Kingdom of Saudi Arabia. International Journal of Business and Management, 8(1). 26.

26. Oolders, T., Chernyshenko, O. S., \& Stark, S. (2008). Cultural intelligence as a mediator of relationships between openness to experience and adaptive performance. Handbook of cultural intelligence: Theory, measurement, and applications. 145-158. 
27. Spencer-Oatey, H. (2008). Culturally Speaking Second Edition: Culture, Communication and Politeness Theory. Bloomsbury Publishing.

28. Sternberg, R. J. (1997). The Concept of Intelligence and Its Role in Lifelong Learning, American Psychologist, 52. 1030-7.

29. Subramaniam, A., Ramalu, I., Wei, C. C., \& Rose, R. C. (2011). The effects of cultural intelligence on cross-cultural adjustment and job performance amongst expatriates in Malaysia. International Journal of Business and Social Science, 2(9).

30. Thomas, D. C., Elron, E., Stahl, G., Ekelund, B. Z., Ravlin, E. C., Cerdin, J. L.,... \& Thorndike, R. L., \& Stein, S. (1937). An evaluation of the attempts to measure social intelligence. Psychological Bulletin, 34(5). 275. $2^{\text {nd }}$ edition. London: Continuum.

31. Triandis, H. C. (1994). Culture and social behavior. New York: McGraw Hill.

32. Warr, P. (1990). The measurement of well-being and other aspects of mental health. Journal of occupational Psychology, 63(3). 193-210.

33. Yildirim, K., Arastaman, G., \& Dasci, E. (2016). The relationship between teachers'attitude toward measurement and evaluation and their perceptions of professional well-being. Eurasian Journal of Educational Research, 62. 77-96. http:/ / dx.doi.org/10.14689/ejer.2016.62.6 